\title{
Multicentre post-infarction trial of propranolol in 49 hospitals in the United Kingdom, Italy, and Yugoslavia
}

\author{
N S BABER, D WAINWRIGHT EVANS, G HOWITT, M THOMAS, C WILSON, \\ J A LEWIS, P M DAWES, K HANDLER, R TUSON* \\ From ICI Pharmaceuticals Division, Macclesfield; Papworth Hospital, Cambridge; \\ Manchester Royal Infirmary; Midhurst Medical Research Institute; and Waveney Hospital, Ballymena
}

SUMMARY A multicentre study of survivors of an anterior myocardial infarction is reported. The trial consisted of 720 patients and was a double-blind, placebo-controlled study with propranolol $40 \mathrm{mg}$ three times a day. Trial entry was at two to 14 days (mean 8.5 days) and follow-up at one, three, and in most centres, six and nine months. The trial was designed to detect a 50 per cent reduction in mortality and this was not shown. The non-fatal reinfarction rate was similar in both groups. Subgroup analysis identified several prognostic risk factors for death, none of which interacted with treatment.

There have been 15 studies with four beta-adrenergic blocking drugs (propranolol, practolol, alprenolol, and oxprenolol) after acute myocardial infarction. ${ }^{1-15}$ In 11 of these studies, ${ }^{1-9} 1415$ the drugs were started within the first 24 to 48 hours. Only in the first study with propranolol ${ }^{1}$ was a reduction in mortality claimed. In another early intervention trial an important subgroup with an initial high heart rate also had a reduced mortality with practolol. ${ }^{14}$ In the other four studies, ${ }^{10-13}$ treatment was started two weeks or more after recovery from the acute attack and was continued for up to three

* N S Baber: co-ordinating secretary; D Wainwright Evans, G Howitt, $M$ Thomas, $C$ Wilson: steering committee; J A Lewis: statistician; P M Dawes, $\mathrm{K}$ Handler: assistant secretaries; $\mathrm{R}$ Tuson: computer services.

Participating physicians: R J Adam, Banbury; N S Al-Mufty, Darlington; D W Barritt, Bristol; J Bell, Reading; I K Brown, Liverpool; J Buchanan, Carlisle; A Campbell, East Kilbride; K Gray, Barnet; J A Cosh, Bath; B K Ellenbogen, Wallasey; C D Eraut, Southend; G C Ferguson, Northampton; T Fyfe, Glasgow; P M S Gillam, Salisbury; D Gooptu, South Shields; K Hollinrake, Nuneaton; G Howitt, Manchester; M H Husaini, Ashton-under-Lyne; I Hutton, Glasgow; G Ismay, Bishops Auckland; G J Jackson, London; D E Jewitt, London; M M Kubik, Dudley; S Lal, Bury; B T McNamee, Dungannon; M Murray, Chelmsford; P D Mulcahy, Plymouth; J G Murtagh, Belfast; R E Nagle, Selly Oak; K A K North, Reading; D Pearson, Warrington; E B Raftery, Harrow; J M Rice-Oxley, Worksop; G H Robb, Epsom; D Robson, London; F Robertson, Bishops Auckland; A J Robertson, Liverpool; G P Sechiari, Ormskirk; H C Smyllie, Doncaster; S P D Snow, Bolton; G S Spathis, Carshalton; B E Taylor, Preston; R L Ward, Blackburn; D A L Watt, Preston; $R$ J Weir, Glasgow; C Wilson, Ballymena.

From Italy: G Folli and F Rovelli, Milan; V Greco, Rome.

From Yugoslavia: I Lambic and P Milankovic, Belgrade.

Received for publicution 21 November 1979 years. Three of these trials yielded significant reductions in mortality with practolol $^{13}$ and alprenolol. ${ }^{11} 12$ The present studies were undertaken to see whether propranolol gave comparable results with those of practolol ${ }^{13}$ in patients with anterior infarction.

\section{Patients and methods}

From a total of 49 hospitals, 720 patients ( 609 men, 111 women) aged 70 or less entered a double-blind placebo-controlled study at two to 14 days (mean 8.5) after anterior infarction. They were started on propranolol or placebo according to a separate random code for each centre, with a dose of $40 \mathrm{mg}$ propranolol thrice daily. Follow-up was at one, three, six, and nine months in 28 centres (Table 1 ). Outpatient facilities were restricted in 21 hospitals

Table 1 Number of patients

\begin{tabular}{lll}
\hline & \multicolumn{2}{l}{ Patients in trial } \\
\cline { 2 - 3 } & Placebo & Propranolol \\
\hline Entry & 365 & 355 \\
1 month & 345 & 328 \\
3 months & 295 & 299 \\
6 months & 147 & 146 \\
9 months & 122 & 123 \\
\hline
\end{tabular}

* In a total of 374 patients the trial duration was only three months. Mean duration in trial: patients on propranolol 172 days; patients on placebo 169 days. 
and so hospital follow-up was made at one and three months only. Subsequent mortality and morbidity in patients beyond three months from these 21 centres was ascertained by direct communication with the doctor and, if necessary, with the patient's general practitioner. At the hospital visits blood pressure, heart rate, side effects, and drug compliance were recorded. Patients withdrawn for various reasons were also followed up and their fate determined.

\section{PATIENT SELECTION}

Diagnosis of anterior myocardial infarction was based on electrocardiographic abnormalities of an anterior infarction defined as "very probable" on WHO electrocardiographic criteria, ${ }^{16}$ plus either a typical history or serum enzyme levels (AST and $\mathrm{LDH})$ at least twice the accepted upper limit of normal or three times if CK was used.

Critera for exclusion included ${ }^{\star}$ : (1) bronchospasm; (2) atrioventricular block greater than first degree; (3) sinus bradycardia ( $<55 /$ minute); (4) persistent heart failure; and (5) beta blockade at time of infarction.

Withdrawal criteria : (1) angina requiring treatment with a beta blocker; (2) bradycardia less than 50 beats/min or heart block greater than first degree; (3) other clinical indications, for example heart failure; and (4) discontinuation of treatment for more than 10 days.

\section{STATISTICAL METHODS}

It was estimated that 1000 patients in each group would be needed to give adequate power to detect a reduction in three month mortality from 4 per cent in the placebo group to 2 per cent in the propranolol group $^{17}$; this assumed reduction was based on the earlier practolol trial results. ${ }^{13} \mathrm{~A}$ precautionary sequential analysis of mortality was also used to avoid excessive prolongation of the study. Analysis of mortality included all deaths in all randomised patients, whether or not they withdrew from the trial. Analysis of potential risk factors and their interaction with treatment was carried out by means of stepwise regression, ${ }^{18}$ and confirmed by means of Cox's proportional hazard regression model. ${ }^{19}$ In stepwise regression the most significant factors are deliberately selected from a large set of possible factors. This leads to significance levels which are too high and which, therefore, must be interpreted cautiously. ${ }^{20}$ *

^ Full details available on request from Dr N S Baber, ICI Pharmaceuticals.

\section{Results}

\section{GROUP COMPARISON}

The two groups were similar in all the factors shown in Table 2.

\section{TRIAL TERMINATION}

When the double-blind trial reached the statistical end-point of no difference, patient recruitment was stopped.

\section{TOTAL DEATHS AND REINFARCTIONS}

The difference in total mortality between the two double-blind groups was not statistically significant (Table 3). The 90 per cent confidence limits on the mortality difference in the trial ranged from a 41 per cent decrease to a 54 per cent increase. There were no significant intergroup differences for timing or mode of death or reinfarction (Tables 3 and 4).

\section{Table 2 Comparability of groups}

\begin{tabular}{|c|c|c|}
\hline History before infarct & Placebo & Propranolol \\
\hline $\begin{array}{l}\text { No. of patients } \\
\text { Mean age }(\mathrm{y}) \\
\text { Percentage male } \\
\text { Percentage female } \\
\text { Mean weight }(\mathrm{kg}) \\
\text { Mean height }(\mathrm{cm})\end{array}$ & $\begin{array}{l}365 \\
54 \cdot 8 \\
83 \\
17 \\
72 \\
170\end{array}$ & $\begin{array}{l}355 \\
55 \cdot 0 \\
86 \\
14 \\
73 \\
170\end{array}$ \\
\hline & & \\
\hline $\begin{array}{l}\text { Percentage positive } \\
\text { Percentage with angina more }\end{array}$ & 40 & 35 \\
\hline & 19 & 15 \\
\hline Previous infarct $(\%)$ & 16 & 15 \\
\hline History of cardiac failure (\%) & 2 & 1 \\
\hline \multicolumn{3}{|l|}{ Concurrent disease: } \\
\hline $\begin{array}{l}\text { Percentage hypertension } \\
\text { Percentage peripheral artery }\end{array}$ & 15 & 13 \\
\hline $\begin{array}{l}\text { Percentage peripheral artery } \\
\text { disease }\end{array}$ & 2 & 1 \\
\hline Percentage with diabetes & 4 & 3 \\
\hline Smokers $(\%)$ & 65 & 64 \\
\hline \multicolumn{3}{|c|}{ Data on original infarct and post-infarct state } \\
\hline diastolic blood pressure after & & \\
\hline $\begin{array}{l}\text { infarct }(\mathrm{mmHg}) \\
\text { Earliest mean }( \pm \text { SE) heart rate }\end{array}$ & $91.4(0.9)$ & $91 \cdot 4(0.8)$ \\
\hline (beats/min) & $84 \cdot 0(1 \cdot 0)$ & $82.2(0.9)$ \\
\hline \multicolumn{3}{|l|}{ Treatment during acute phase } \\
\hline $\begin{array}{l}\text { Percentage DC shock } \\
\text { Percentage drug treatment }\end{array}$ & 4 & 5 \\
\hline other than beta blockers & 88 & 86 \\
\hline $\begin{array}{l}\text { Percentage receiving beta } \\
\text { blockers }\end{array}$ & 7 & 5 \\
\hline \multicolumn{3}{|l|}{$\begin{array}{l}\text { Percentage with cardiac failure } \\
\text { in acute phase }\end{array}$} \\
\hline to entry & $8 \cdot 4$ & $8 \cdot 4$ \\
\hline \multirow{4}{*}{$\begin{array}{l}\text { Mean }( \pm \text { SE) systolic BP at } \\
\text { entry }(\mathrm{mmHg}) \\
\text { Mean }( \pm \mathrm{SE}) \text { diastolic BP at } \\
\text { entry }(\mathrm{mmHg}) \\
\text { Mean }( \pm \mathrm{SE}) \text { heart rate at entry } \\
\text { Percentage with ventricular } \\
\text { ectopics at entry }\end{array}$} & $124 \cdot 2(1 \cdot 0)$ & $122.8(0.9)$ \\
\hline & $79 \cdot 7(0 \cdot 6)$ & $79 \cdot 2(0.6)$ \\
\hline & $81.9(0.6)$ & $81 \cdot 3(0 \cdot 7)$ \\
\hline & 7 & 6 \\
\hline
\end{tabular}


Table 3 Total deaths and reinfarctions in all randomised patients at 9 months

\begin{tabular}{lcllll}
\hline & \multicolumn{2}{l}{ Placebo } & & \multicolumn{2}{l}{ Propranolol } \\
\cline { 2 - 3 } \cline { 5 - 6 } \cline { 5 - 6 } & No. & Per cent & & No. & Per cent \\
\hline Cardiac deaths in trial & 18 & 4.9 & & 19 & 5.4 \\
Non-cardiac deaths in trial & 2 & 0.5 & & 3 & 0.8 \\
$\begin{array}{l}\text { Cardiac deaths after withdrawal } \\
\text { Non-cardiac deaths after }\end{array}$ & 7 & 1.9 & & 6 & 1.7 \\
withdrawal & 0 & 0 & & 0 & 0 \\
\hline Total deaths & 27 & 7.4 & 28 & 7.9 \\
\hline Non-fatal reinfarctions in trial & 14 & 3.8 & 15 & 4.2 \\
Non-fatal reinfarctions after & 1 & 0.3 & 0 & 0 \\
withdrawal & & & &
\end{tabular}

Per cent expressed as a percentage of number entering the study.

Table 4 Time from entry to death-total mortality

\begin{tabular}{lll}
\hline Time from entry (months) & Placebo & Propranolol \\
\hline 1 & 14 & 18 \\
1 to 3 & 6 & 3 \\
3 to 6 & 6 & 4 \\
6 to 9 & 1 & 3 \\
\hline
\end{tabular}

\section{PROGNOSTIC FACTORS AND RELATION TO TREATMENT}

Six prognostic factors independent of a treatment effect were identified (Table 5). The overall mortality correlated positively with age and with entry heart rate. Mortality was also higher in patients with arrhythmias at entry.

Attempts were made to relate any effect of treatment on mortality to the six prognostic factors above and also to other factors such as blood pressure (Table 6) (immediately on admission and at entry) and congestive cardiac failure (Table 7). However, no statistically significant relation was found for any of the factors $(p>0.05)$.

Table 5 Risk factors for mortality independent of treatment

\begin{tabular}{ll}
\hline Age & Definite \\
Heart rate at trial entry & $\mathrm{p}<0.005$ \\
Arrhythmias at entry & \\
\hline Female sex & Possible \\
Smoking & $\mathrm{p}<0.1$ \\
History of myocardial infarction & \\
\hline
\end{tabular}

Table 6 Deaths related to acute systolic and entry diastolic blood pressures

\begin{tabular}{lcc}
\hline & Placebo & Propranolo \\
\hline $\begin{array}{l}\text { No. (\%) deaths with acute systolic } \\
\text { blood pressure above mean }\end{array}$ & $14(8 \cdot 2)$ & $10(6 \cdot 7)$ \\
$\begin{array}{c}\text { No. (\%) deaths with acute systolic } \\
\text { blood pressure below mean }\end{array}$ & $13(6 \cdot 7)$ & $18(8 \cdot 8)$ \\
$\begin{array}{c}\text { No. (\%) deaths with entry diastolic } \\
\text { blood pressure above mean }\end{array}$ & $21(9 \cdot 5)$ & $15(7 \cdot 3)$ \\
$\begin{array}{c}\text { No. (\%) deaths with entry diastolic } \\
\text { blood pressure below mean }\end{array}$ & $6(4 \cdot 2)$ & $13(8 \cdot 7)$ \\
\hline
\end{tabular}

Table 7 Death rate by signs of congestive cardiac failure in acute phase

\begin{tabular}{lrlrlr}
\hline & \multicolumn{2}{l}{ Placebo } & & \multicolumn{2}{l}{ Propranolol } \\
\cline { 2 - 3 } \cline { 5 - 6 } \cline { 5 - 6 } & No. & Per cent & & No. & Per cent \\
\hline Congestive cardiac failure: & 22 & 7.6 & & 21 & 7.3 \\
Absent & 5 & 6.5 & & 7 & 10.6 \\
\hline
\end{tabular}

WITHDRAWALS (Table 8)

There were no statistically significant differences between the two groups.

\section{OPEN TRIAL}

In parallel with the double-blind, placebo-controlled trial, an open study, using $40 \mathrm{mg}$ propranolol three times a day, was also conducted in 500 patients by doctors in 37 hospitals who, because of the practolol multicentre trial findings, ${ }^{13}$ were unwilling to consider randomising. There were three findings of particular interest from this study:

(1) Comparability of patients at trial entry (8.5 days) with both groups of the double-blind trial.

(2) A similar total mortality (31/501 entered: $6 \cdot 2 \%$ ) at nine months.

(3) A more precise estimate of risk factors independent of treatment was possible by inclusion of this group (Table 5).

Table 8 Reasons for withdrawal from trial (these are not mutually exclusive)

\begin{tabular}{lcc}
\hline & Placebo & Propranolol \\
\hline Reinfarction & 9 & 10 \\
Cardiac failure & 22 & 22 \\
Cardiac failure alone & 17 & 10 \\
Angina & 13 & 7 \\
Arrhythmias & 11 & 7 \\
Adverse reaction & 5 & 42 \\
Other & 38 & $82(23 \%)$ \\
\hline Total number of patients & & \\
$\quad$ withdrawn & $88(24 \%)$ & \\
\hline
\end{tabular}




\section{Discussion}

The findings indicate no difference in mortality throughout the nine months of follow-up after anterior myocardial infarction, between those given propranolol (40 mg thrice daily) and placebo. These results merit close examination, because they demonstrate some important features in the design, execution, and interpretation of such trials.

The design of the study took into account the experience gained from the practolol multicentre study. ${ }^{13}$ The number of patients required was estimated on the basis that propranolol might produce a comparable reduction in mortality to that of practolol, that is 50 per cent.

Propranolol may produce a reduction in mortality of less than 50 per cent, and this is still possible within the confidence limits of the result (Fig). The dismissal of potentially useful agents because of an inadequate sample size or the reporting of "no difference" between treatment and control when only very large differences have been considered, has been recently reviewed. ${ }^{21}$ In the example given in that reference (which was a propranolol post-infarction trial) there was a 77 per cent risk of missing a real difference of 25 per cent reduction in mortality, and a 42 per cent risk of missing a difference of 50 per cent. The Figure gives the 90 per cent confidence limits for the true percentage difference in mortality rates for all propranolol trials. In seven of the eight trials, a 25 per cent reduction in mortality cannot be excluded; in six of the eight studies, a 50 per cent reduction cannot be excluded.

In the present study the lower confidence limit does not exclude a possible reduction of 40 per cent but much larger numbers of patients would have been required to show this smaller difference (approximately 1700 per group). It is pertinent to ask whether a smaller reduction in mortality, if proven, would warrant the widespread use of a betablocking agent for all anterior infarction patients. A recent editorial by Rose $^{22}$ develops this argument. The annual mortality after an uncomplicated anterior infarction is about 6 per cent, ${ }^{13}$ and if a 30 per cent reduction in this mortality could be achieved, then in every 100 patients treated, two patients would benefit.

Another consideration concerns the possibility that harm to specific patient subgroups outweighs benefit to others. However, this was not shown in this trial. In particular, there was no evidence that more patients died in congestive cardiac failure or were withdrawn from the trial because of this complication in the propranolol group compared with placebo.

In the practolol multicentre study, patients with an anterior infarction whose trial entry diastolic blood pressure was equal to or below the mean $(78 \mathrm{mmHg})$ and who received practolol, had only one-sixth the mortality, compared with their respective placebo group (24 deaths on placebo versus four deaths on practolol). Interactions of blood pressure and treatment were sought in the present study, but none of these reached significance at the 5 per cent level.

Detailed comparison with the practolol trial is not appropriate, but possible pertinent differences include: size of trials, differences between patient groups, differences in pharmacological profiles, and differences in the time courses of beta blockade. ${ }^{23} 24$

We are grateful to Dr K Green and Mr S H Ellis for advice.

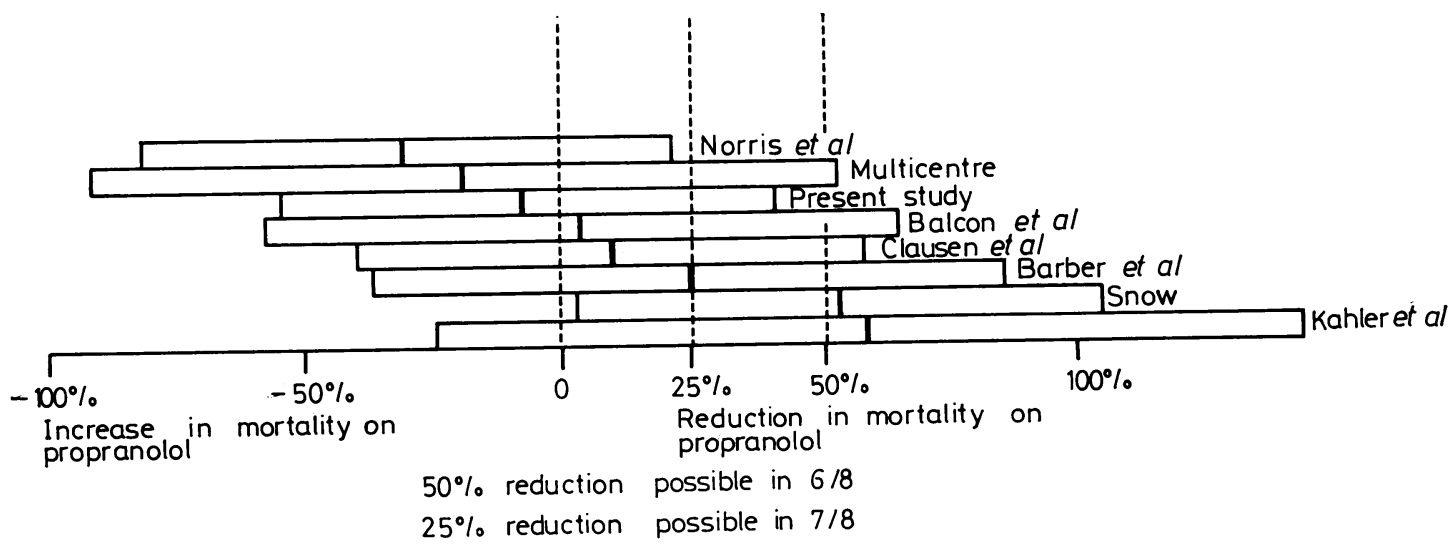

Fig. Difference in mortality rates with 90 per cent confidence limits expressed as a percentage of observed control rate in eight controlled trials of propranolol. 


\section{References}

1 Snow PJD. Effect of propranolol in myocardial infarction. Lancet 1965; ii: 551-3.

2 Balcon R, Jewitt DE, Davies JPH, Oram S. A controlled trial of propranolol in acute myocardial infarction. Lancet 1966; ii: 917-20.

3 Clausen J, Felsby M, Schønau Jørgensen F, Lyager Nielsen B, Roin J, Strange B. Absence of prophylactic effect of propranolol in myocardial infarction. Lancet 1966; ii: $920-4$.

4 Multicentre trial. Propranolol in acute myocardial infarction. Lancet 1966; ii: 1435-8.

5 Barber JM, Murphy FM, Merrett JD. Clinical trial of propranolol in acute myocardial infarction. Ulster Med f 1967; 36: 127-30.

6 Sloman G, Stannard M. Beta-adrenergic blockade and cardiac arrhythmias. $\mathrm{Br}$ Med $\mathcal{F} 1967$; iv: 508-12.

7 Kahler RL, Brill SJ, Perkins WE. The role of propranolol in the management of acute myocardial infarction. In: Kattus AA, Ross G, Hall VE, eds. Cardiovascular beta-adrenergic responses. Los Angeles: University of California Press, 1970: 213.

8 Norris RM, Caughey DE, Scott PJ. Trial of propranolol in acute myocardial infarction. $\mathrm{Br} \mathrm{Med} \mathcal{f}$ 1968; ii: 398-400.

9 Fuccella LM. Report on the double-blind trial with compound CIBA 39 089-Ba (Trasicor), in myocardial infarction. Quoted by Sowton E. Beta adrenergic blockade in cardiac infarction. Prog Cardiovasc Dis 1968; 10: 561-74.

10 Reynolds JL, Whitlock RML. Effects of a betaadrenergic receptor blocker in myocardial infarction for one year from onset. Br Heart $\mathcal{F} 1972$; 34: 252-9.

11 Wilhelmsson C, Vedin JA, Wilhelmsen J, Tibblin G, Werkö L. Reduction of sudden deaths after myocardial infarction by treatment with alprenolol. Lancet 1974; ii: 1157-60.

12 Ahlmark G, Saetre H, Korsgren M. Reduction of sudden deaths after myocardial infarction (letter). Lancet 1974; ii: 1563.

13 Multicentre International Study. Improvement in prognosis of myocardial infarction by long-term betaadrenoreceptor blockade using practolol. $\mathrm{Br}$ Med $\mathcal{F}$ 1975; iii: 735-40.

14 Barber JM, Boyle DM, Chaturvedi NC, Singh N, Walsh MJ. Practolol in acute myocardial infarction. Acta Med Scand 1975; suppl 587: 213-9.

15 Norris RM, Clarke ED, Sammel NL, Smith WM, Williams B. Protective effect of propranolol in threatened myocardial infarction. Lancet 1978; ii: 907-9.

16 World Health Organization. The electrocardiogram in coronary heart disease. WHO Tech Rep Ser 1959; 168: $25-8$.

17 Burdette WJ, Gehan EA. Planning and analysis of clinical studies. Springfield, Illinois: Charles C Thomas, 1970: 36.

18 Draper NR, Smith H. Applied regression analysis. New York: John Wiley, 1966: 163.

19 Cox DR. Regression models and life tables. $\mathcal{F R}$ Stat Soc 1972; B34: 187.

20 Pope T, Webster JT. The use of an F-statistic in stepwise regression procedures. Technometrics 1972; 14: 327.

21 Freiman JA, Chalmers TC, Smith H Jr, Kuebler RJ. The importance of beta, the type II error and sample size in the design and interpretation of the randomized control trial: survey of 71 "negative" trials. $N$ Engl f Med 1978; 299: 690-4.

22 Rose G. Population screening for myocardial ischemia. Am Heart $\mathcal{f}$ 1978; 96: 427-9.

23 Bodem G, Chidsey CA. Pharmacokinetic studies of practolol, a beta adrenergic antagonist in man. Clin Pharmacol Ther 1973; 14: 26-9.

24 Carruthers SG, Kelly JG, McDevitt DG, Shanks RG, Walsh MJ. Blood levels of practolol after oral and parenteral administration and their relationship to exercise heart rate. Clin Pharmacol Ther 1974; 15: 497-509.

Requests for reprints to Dr N S Baber, ICI Pharmaceuticals, Mereside, Alderley Park, Macclesfield, Cheshire SK10 4TG. 